\title{
ON THE BIOLOGICAL TERM "GENE" IN THE HISTORY OF SCIENCE
}

\author{
Kurt PlischKe \& Alfons LABISCH \\ Universität Düsseldorf
}

\begin{abstract}
AвSTRACT: Contemporary philosophy of science sets the origins of the predominant attributes of the term "gene" in the year 1900 when Gregor Mendel's work was rediscovered. Yet it was the speculative biology of the second half of the $19^{\text {th }}$ century that opened up the epistemic sphere for a new conception of heredity: heredity as the transmission of particulate, hereditable material units with a tendency for self-preservation. The then young discipline of biology dissociated its terminology from the preconceptions of natural philosophy. In the early $20^{\text {th }}$ century, the postulated hereditary particles were associated with the chromosome and, at least in the 1940s, with nucleic acid: which was being stable and, at the same time, mutable, as well as capable of self-reproduction, self-selectivity, and memory. DNA epitomizes the perfect biological principle. But the most recent conception of the gene is not free from anthropomorphisms.
\end{abstract}

KEYwORDS: philosophy of nature, speculative biology, materialistic reductionism, natural purpose, final causation, anthropomorphism.

\section{Introduction}

The current science philosophy dates back the beginning of the modern concept of the gene to the scientific discourse beginning with the rediscovery of Mendel's hereditary rules. Their experimental verification, with the formation of the microbiological access and the molecular-biological description, gave rise to the modern features of the gene concept. In this sense the molecularbiological formula of the gene originated, taking into account Darwin's premises on the theory of evolution, what, except Mendel's, was supposedly the only contribution of the 19th century. The molecular formula appeared to have met the modern ideal of science: mechanical-physical causality of the living, as 
defined by the epistemological principles which emerged in the 19th century in withdrawal from natural philosophy. Darwin's primary aim - the elimination of anthropomorphism and teleological causal understanding in biology - is considered to be achieved, since the gene is described as the automatism and the chemical mechanism of a self-duplicating DNS.

In this paper is shown that the decisive influence on the present gene concept goes back in detail to the pre-experimental, speculative preparatory work of the previous epoch and their scientists. At first the current positions are shown, which characterize the standpoint of today's history of science on the origin of the gene concept (chapter 2). In the following chapter the question about the influences of the time before the rediscovery of Mendel's work is furthermore justified (chapter 3). Subsequently it is demonstrated how and in which details preconceptions in the 19th century developed in confrontation with the philosophy of nature (chapter 4), organizing the further experimental development of the gene concept (chapter 5). By retracing these historical paths the thesis of this paper is verified: the results of the early period are reflected in the modern term. The conclusion for the causality understanding of genetics is: the goal to eliminate anthropomorphism by a purely mechanistic theory of inheritance failed (chapter 6).

A history of the origins of the attributes of the biological term "gene" must take into account the development of biology as a young discipline in its own right in the realm of the sciences. Genetics as an independent research field within biology was not developed until the $20^{\text {th }}$ century. It emerged from the notion that a specialized substance must be responsible for heredity, which was first established as early as in the second half of the $19^{\text {th }}$ century. Terminology varied greatly. It evolved in a dispute that lasted decades, was oftentimes merely theoretical and later continued under the experimental practices of the period that followed.

\section{Positions on the origin of the term "gene" in current scientific theory}

The attributes of the term "gene" as it is used currently in biology can be traced back to the rediscovery of Gregor Johann Mendel's (1822-1884) groundbreaking work Versuche über Pflanzenhybriden (Experiments on Plant Hybrids) (Mendel, 1865; Bateson, 1902). William Bateson (1861-1926), introducing 
the term genetics while defining this new science in 1906, made the point that the development of evolutionary biology entirely would have taken another run if Darwin had noticed Mendel's works, as the German zoologist Ingo Krumbiegel (1903-1990) marks $(1957,55)$. But the scientific world did not become aware of it until 1900 when it was referred to in three individual publications. Carl Erich Franz Joseph Correns (1894-1933), Erich Tschermak von Seysenegg (1871-1962) and Hugo Marie De Vries (1848-1935) had all found similar numerical proportions to Mendel's in their research and pointed out the importance of Mendel's findings and the conclusions derived from them. For Correns Mendel's most important result was his record of separate and arbitrarily relocatable internal dispositions for the later appearing external features of the organism $(1905,190)$. So the time of thought experiments would be over and in decades of tiresome work a stable scientific frame should be established of which its cornerstone Mendel had advanced $(1912,75)$. Tschermak pointed to the necessity of a re-examination of the experiments about the inheritance of peas because Darwin had examined only four pairs hence being unable to reach exactness (1900, 232). De Vries recognized a general importance in Mendel's rules about the transmission of inheritable units for detecting units by which the features of species would be composed $(1900,90)$. Mendelism was established in the course of the following decade. The growing knowledge about the components of cells and their functions in reproduction could be brought into accordance with Mendel's laws. The opposition between Darwinists and Mendelists was reconciled with the help of the New Synthesis. From this point of view the decisive turning point in the history of the gene-concept is placed after the 19th century, still a period of mostly pre-experimental considerations while biology emerged as a discipline in its own right within the realm of the sciences.

In his very useful Short History of Genetics, Leslie Clarance Dunn (18931974), the founder of the American Society of Human Genetics and in 1960 the president of the U.S. National Academy of Sciences, points out that the period from 1900 to 1906 "can now be seen as the chief break in the continuity of ideas about the transmission system of heredity" $(1965,33)$. What had been developed earlier - with the exception of Mendel - had only very little influence on the evolution of ideas. Lindley Darden $\left({ }^{*} 1943\right)$ believes that the central turning point was when Mendel's discrete particles were replaced by the term factor as a consequence of Mendelism gaining general acceptance in the first decade of the 20th century. The introduction of the term gene and its development to the chromosome-related gene would be the consequence of this terminological decision $(1991,178)$. Elof Axel Carlson $\left({ }^{*} 1931\right)$ claims that the rediscovery of 
Mendel and its consequences formed the beginning of the development, namely when William Bateson equated hereditary elements and factors with units of traits $(1971,1)$. He adds, however, that the concept of hereditary units within the theory of the gene can be traced back to Darwin's theoretical contribution in his provisional hypothesis $(1971,96)$. And he points to the fact that in the history of the gene since Darwin, Spencer and Mendel, uncountable problems with no solution would have led to contradictions. Even geneticists contradicted one another in defining the gene although using the same model-organism. Robert Cecil Olby $\left({ }^{*} 1933\right)$ provided an acclaimed historical overview with The Path to the Double-Helix. He indicates that Johann Friedrich Miescher had already proposed a nuclein concept in 1869 . Yet, he continues, the modern model could neither be derived from this nor from any other conception of that time. Olby believes there has been a veritable break between two stages. "I therefore concluded that the difference between the nineteenth century conception at these substances and the precise picture of the, albeit ill-famed, tetranucleotide which emerged [...] between 1909 and 1929 was so great that it was advisible to exclude the pre-1900 period of work on DNA" (1974, XIX-XX). He says the period to be considered should be limited to 1900 to 1953 .

Objections were voiced against the view, which had become fashionable in science, that the actual turn consisted in the discovery of the molecular components of the genetic material. The assimilation of theories from different sources might have been more influential on the scientific path to the gene, it was said, than the description of the molecular composition of some heredity substance. According to Thomas Cremer $\left({ }^{*} 1945\right)$, the crucial turning point in the history of the biological theory of heredity evolved as a consequence of a new doctrine that emerged in the 19th and early 20th century. The paradigm of hereditary factors that are located separately on chromosomes, he explains, was the logical consequence of the combination of biological approaches to heredity and Darwinism:

The emergence of theories that postulated particulate inheritance by means of some heredity substance to be found in chromosomes in combination with the debates about the problem of the evolution of living things taking place at the same time appears to have been [...] the true scientific revolution in the development of biology, more significant for the history of thought than the solving of the question of the molecular nature of this 
heredity substance that occurred later and as a consequence of those earlier theories. $(1985, \mathrm{XI}){ }^{1}$

As Cremer explicates, the crossbreeding-experiments following Mendel's paradigm would have enabled genetics to make up the idea of particulate inheritance by means of genes. The affiliation of this paradigm to evolutionary theory would have caused the decisive historical break. One of the leading geneticists of the USA, Bruce Wallace $\left({ }^{*} 1920\right)$, also underlines the importance of the decision in favor of one theory. For Wallace, the beginning of genetics as a science was when Mendel's theorem was rediscovered in 1900. He marginalizes the influence of researchers like Charles Darwin (1809-1882), Ernst Haeckel (1834-1919), August Weismann (1834-1914), Carl Wilhelm Nägeli (1817-1891), Oskar Wilhelm Hertwig (1894-1922) or, in some cases, does not even mention them. "Classical biology relied heavily on verbal descriptions of observations that, when articulated with sufficient skill, became accepted as explanations" (Wallace, 1992, VIII). The second decision in the history of the gene, when in 1953 the genetic principle was pictured as DNA-doublehelix, seems to Wallace to be the mental goal of the whole course of knowledge, the reduction of genetics to chemistry.

Contemporary history and philosophy of science ascribes, at most, a minor influence on today's terminology to the groundwork done in the $19^{\text {th }}$ century, with the exceptions of the likes of Mendel and Darwin, and that even only regarding the formation of the concepts, not the attributes of the term gene. This is in stark contrast with the fact that the epistemic sphere for this new conception of heredity was created precisely in those theoretical considerations, in the still fundamental disputes of the second half of the $19^{\text {th }}$ century: "when the organisms were given a $>$ history $<$ and life forms were no longer determined by pre-established species boundaries" (Rheinberger/Müller-Wille, 2009, 106).

Evelyn Fox Keller $\left({ }^{*} 1936\right)$ is significantly opposed to the views described above with her publication The Century of the Gene. There she explains that a crucial component of the term "gene" was already present in its origins, long before the word gene was even coined. The determinants from August Weismann's germline theory or Hugo de Vries' pangenes are, according to her, "still direct

\footnotetext{
${ }^{1}$ If not otherwise stated, translations are of K. Pl.
} 
the precursors of the gene, and inevitably some of the preconditions underlying these earlier concepts carried over" $(2000,19)$.

Lily Kay (1947-2000) claims the break came at an entirely different time. In her book Who Wrote the Book of Life? she traces a "history of the genetic code". The fundamental rupture in representations, she argues, occurred in the 1950s: The conception of the gene was transformed from a material and energetic one to an informational one. She goes on to explain that reducing biological processes to molecular biology turns information into a metaphor for biological specificity (2000, XVI, 2, 55, 328). As she explains, the term genetic code was not a truth deduced from nature or from the structural relations of the DNA-molecule.

Hans-Jörg Rheinberger $\left({ }^{*} 1946\right)$ and Staffan Müller-Wille $\left({ }^{*} 1964\right)$ hold an inter-mediary point of view. They think that the logical precursor of the modern term "gene" was Wilhelm Johannsen's differentiation between the genotype and the phenotype: "We can be sure in saying that it established $<$ the gene $>$ as an epistemic object that had to be examined in its own sphere" $(2009,62)$.

This differentiation was prepared by authors of the $19^{\text {th }}$ century. They posited separate forces of heredity that - during long, speculative disputes - they located in a more or less specialized substance that was discontinuous from the building blocks of organisms. Thus they gave up some of the main propositions of Darwin's provisional hypothesis while maintaining other parts of his theory.

\section{The question about origins of the concept as a result of his prehistory}

There is no or hardly any basic research using the original texts of the researchers from the early period, which would show in a coherent and conclusive way how attributes of the term were introduced, derived from and substantiated by one another. Instead, the main ideas of different doctrines of heredity were compared and the sources named. There is no detailed terminology work, in particular regarding the term "gene" as it was prepared during the so-called speculative period of the $19^{\text {th }}$ century, before it was first defined by Wilhelm Johannsen (1857-1927) in 1903 and before the name genetics was introduced by William Bateson in 1906 (Bateson 1907). ${ }^{2}$ Are there any indications of early

2 The first introduction and definition of the term gene Johannsen gave was in a course of lectures at the University of Copenhagen in 1903. Two years later he published the lectures in 
ventures in this direction from the time when physiology became the leading paradigm in biology, when organic processes were increasingly explained through adaptations to the processuality in chemistry and physics? Did the developments during the early years of biology - the name was first used to denote an independent science in 1800 - really not have an influence on the definition of precise components of the term as it was later formed in Mendelism and New Synthesis (Neo-Darwinism)? Were they later reflected in the experimental systems of classical genetics as introduced by Edmund Beecher Wilson (1856-1936) (cf. Wilson 1897), Thomas Hunt Morgan (1866-1945) (cf. Morgan 1917), Calvin Blackman Bridges (1885-1938) (cf. Bridges 1916), Alfred Henry Sturtevant (1891-1970) (cf. Sturtevant 1913)?3 Are there significant characteristics shared with the apparently substantially proven models presented in 1953 by Francis Harry Compton Crick (1916-2004) in collaboration with James Dewey Watson (*1928) (cf. Watson/Crick 1953a, 1953b), Rosalind Elsie Franklin (1920-1958) and Raymond G. Gosling (1926-2015, (cf. Franklin/Gosling 1953), Maurice Hugh Frederick Wilkins (1916-2004), Alexander Rawson Stokes (1919-2003) and Herbert Rees Wilson (1929-2008) (cf. Wilkins et. al. 1953), characteristics that, in a strict sense, go back to the early years of the gene, before its current definition was even spelled out?

It cannot be seen as an objection against such questions that there was never a complete consensus about the definition of the term "gene". Also, at times definitions could be largely agreed upon. Unanimity was particularly great about the DNA model, the principles of which seemed to be universalizable until well into the 1970s. Later contradictions within genetics and between the conceptions of genes in different biological disciplines (genetics, molecular biology, biology of embryonic development, evolution research, population statistics) found common ground in the most recent synthesis Evolutionary Developmental Biology (Evo-Devo): the gene as a develop-mental system, not solely accountable for the formation of traits, not immediately corresponding to body features, not the only causal agent for their hereditary transmission, but rather just as dependent on the surrounding resources of the entire life cycle, an environment that helps shape epigenetically: the developmental system "gene", a highly redundant structure

the Danish language, Arvelighedslaerens elementer (Johannsen 1905), until he presented them by the more common scientific paper Elemente der exakten Erblichkeitslehre in the German language (Johannsen (1909).

${ }^{3}$ Here Sturtevant proposed the first genetic map by presenting five genes on the X-chromosome of drosophila flies (Carlson, 1971, 67; Johansson, 1988, 60). 
(another term from information theory), gradually embedded in its different surroundings cell, tissue, organ, organ system, organism, habitat, species, population - a description that cannot do without the metaphor of information. Erwin Schrödinger (1887-1961) had described the peculiarity of the heredity substance in the terms of telecommunications technology in his lectures on What is Life? held at Trinity College during the Second World War (Schrödinger 1967 [1944]).

The paradigm shift is also reflected in the science itself. The gene became the organizing principle of biology in the $20^{\text {th }}$ century (Keller, 2000; Moss, 2003; Rheinberger/Müller-Wille, 2009).

The method of the study presented here consists in retracing the paths of the term "gene" in the history of science, beginning with the origins of biology as it established itself in the $19^{\text {th }}$ century up until the acceptance of the DNA. The leading role of genetics that later occurred cannot be explained without references to early terminology with its speculative orientation and to the objectives during the paradigmatic change of biology to become a life science and its establishment as an independent science in the $19^{\text {th }}$ century.

\section{Preformed decisions in the philosophy of nature and reactions to this: mechanical materialistic representations of speculative biology}

Gottfried Reinhold Treviranus (1776-1837), a medical doctor and professor of mathematics and medicine in Bremen, was one of the scientists who introduced the term "Biologie" in the german language. He defined it as a separate science with an own scope of tasks:

The objects of our investigations will be the different forms and phenomena of the life, the conditions and laws under which this state takes place and the causes, by which the same is caused. We will call the science which deals with these objects with the name biology or theory of life. (1802, 3. In the original in the German language in spaced type). 
With this definition for an own field of investigation under the title biology, as the historian of the natural sciences, Brigitte Hoppe $\left({ }^{*} 1935\right)$, explains, a paradigm shift was given in the science of the animated nature. Treviranus moved the natural-philosophical concept "life" in the centre of the scientific consideration instead of the single living being. He did this with reference to Immanuel Kant's perception of animated substance. (Hoppe 1978, 104-188, esp. p. 137).

Kant (1724-1804) also had examined the question whether living creatures followed only mechanist causes according to Isaac Newton, Aristotle's causa efficiens or also teleological ones (causa finalis) in the second part of his Critique of the Power of Judgment, the Critique of Teleological Judgement. Explaining that living beings cannot be imagined without the latter, Kant introduced the concept of the living creature as a purpose in itself:

(A) thing exists as a natural end if it is cause and effect of itself (although in a two-fold sense); for in this there lies a causality the likes of which cannot be connected with the mere concept of a nature without ascribing an end to it, but which in that case also can be conceived without contradiction but cannot be comprehended. (2000, 243. Bold type in the original).

The reasons he gives are:

In such a product of nature each part is conceived as if it exists only through all the others, thus as if existing for the sake of the others and on account of the whole, i.e., as an instrument (organ) [...]; rather it must be thought of as an organ that produces the other parts (consequently each produces the others reciprocally), which cannot be the case in any instrument of art, but only of nature, which provides all the matter for instruments (even those of art); only then and on that account can such a product, as an organized and self-organizing being, be called a natural end (2000, 245 . Bold type in the original). ${ }^{4}$

\footnotetext{
${ }^{4}$ It is often emphasized that Kant's thesis on the status of teleological propositions is less of an ontological than an epistemological one. This objection is justified. However this did not affect considerably the development of the natural sciences, which have already emancipated themselves from philosophy, as the natural scientists argued rather more in general terms against what they think as the natural philosophy of Kant, Schelling and Hegel. As to the
} 
Georg Wilhelm Friedrich Hegel (1770-1831) agreed on that with Kant and conceived a deductive system of nature through mere deduction of terms. He offered the following definition of organisms. In 1830 Hegel wrote in the Encyclopedia, $\$ 352$, a living thing "exists only if it makes itself what it is; it is a precedent purpose that is itself only the result". (1992 [1830], 353). ${ }^{5}$

Following the proposition of Kant and Hegel, the living organism - and this is where it is different from artificial creations - epistemologically can be understood to consist of both at the same time, its purpose of growth and development as well as the cause for it, its efficient cause as well as its final cause. Such causality does not exist anywhere in nature, with the exception of organisms. This position was given up in the course of the $19^{\text {th }}$ century. Still the problem of teleological causality continued to be a dominant topic in numerous examinations and disputes for a long time. The newly developing terminology for genetically active powers of reproduction is proof of a persistent striving for descriptions without final causes.

On the way to a materialistic, unifying reductionism, Herbert Spencer (18201903) suggested the introduction of the term of organic polarity in 1864 . He claimed that, in contrast to chemical and morphological units, vitalized molecules that were polar and tended towards a certain kind of organization had to be posited. He continued that those had to be logically positioned between chemical and organic units according to their intrinsic capacities. Spencer called them physiological units:

(T)he living particles composing one of these fragments, have an innate tendency to arrange themselves into the shape of the organism to which they belong. We must infer that a plant or animal of any species, is made up of special units, in all of which there dwells the intrinsic aptitude to aggregate into the form of that species [...]. (T)he vitalized molecules composing the tissues, show their proclivity towards a particular arrangement $[\ldots]$. It

philosophical side Jacinto Rivera de Rosales Chacon presents an exceedingly informative interpretation of the Kantian teleological dialectics (2017).

${ }^{5}$ In the first edition of the Encyclopedia in 1817 Hegel had given a natural philosophical premise for this thesis $(\$ 195)$. Nature would consist of a system of steps, every step resulting from the precedent one. In the development of nature the steps were not naturally produced one by another, but by the internal idea which constitutes the causal basis of nature (2000, $114)$. In the 1830 edition of his Encyclopedia ( $\$ 249)$ Hegel added, the dialectical term transferring the steps would be the internal cause of this fundamental natural process (1992, 239). Typical for nature is formality. It makes the differences to fall apart and creates them into indifferent beings. 
cannot be that the atoms of albumen, or fibrin, or gelatin, or the hypothetical protein-substance, possess this power of aggregating into specific shapes [...]. Hence, what we may call the chemical units, are clearly not the possessors of this property. On the other hand, this property cannot reside in what may be roughly distinguished as the morphological units. [...] (W) e are forbidden to ascribe to cells this peculiar power of arrangement. [...] If, then, this organic power can be possessed neither by the chemical units nor the morphological units, we must conceive it as possessed by certain intermediate units, which we may term physiological. (1864, 180-183. Italics in the original).

Thanks to the characteristic attribute of having a tendency towards a certain kind of organization, the term of the physiological unit contains a teleological component that is needed to explain the capacity of those units to organize matter. The example Spencer gives is the process of regeneration as it can be observed with begonia. The living particles of the disconnected part of the plant have the innate tendency to put themselves into the shape of the whole plant. Similarly the hypothetic subunits of living matter must be specific units equipped with an intrinsic aptitude for unifying into the shape of the relating species.

For Charles Robert Darwin (1809-1882), this characteristic of certain particles was ensured through their provenance and microcosmic identity with the original structures. Every part of the organism contributes to the reproduction of the ensemble by shedding little seeds, he went on to explain:

I assume that cells, before their conversion into completely passive or "formed material," throw off minute granules or atoms, which circulate freely throughout the system, and when supplied with proper nutriment multiply by self-division, subsequently becoming developed into cells like those from which they were derived. These granules for the sake of distinctness may be called cell-gemmules, or, as the cellular theory is not fully established, simply gemmules. They are supposed to be transmitted from the parents to the offspring, and are generally developed in the generation which immediately succeeds, but are often transmitted in a dormant state during many generations and are then developed. [...] Gemmules are supposed 
to be thrown off by every cell or unit, not only during the adult state, but during all stages of development. (1868, 374).

Darwin elaborated that the gemmules, which he compared with the cells of the body being activity centers, were - just like the living being as a whole dominated by the struggle for life in which they were also in conformity with the premise of the selection hypothesis. Darwin called his assumption about a mechanism for heredity through gemmules that could be transferred from one generation to the next his provisional hypothesis of pangenesis. The component "gene" in the word "pangenesis" and the term "pangene", which was later introduced by Hugo De Vries, is an early notation of the term, which comes close to the modern terminology for heredity units not just in the wording, but also in the extent of its content. The original term "pangene" also has an archetypical sound to it thanks to its composition from ancient Greek elements. However, in his theory Darwin did not explicitly refer to Newton with his ideal of science that is restricted to mechanics.

In contrast to Darwin, Ernst Haeckel (1834-1919) declared that "in the future the entirety of organic development phenomena must be explained strictly mechanically, with the help of physical and chemical elementary processes" $(1876,17) .6$ But, again differing from Darwin, he still believed that "without postulating an atom-soul the most common and most general phenomena in chemistry cannot be explained" $(1876,38)$. Like other scientists of his time, Haeckel believed that heredity can be put down to a special kind of molecule. He introduced the term plastidule to denote entities that have a capacity of

\footnotetext{
${ }^{6}$ It may be worth mentioning that Haeckel believed his concept would logically be deducible from Aristotle's arguments. Aristotle would have regarded the mechanical principle of movement as the most important cause of the individual development $(1876,71)$. Indeed in De generatio animalium Aristotle describes the processes of heredity as transfer of material movements (kineseis). But in this materialistic aspect must be noted that natural movements for Aristotle are caused by four groups of causes, materiality, formality, efficient causality and final causality as exposed in Metaphysics I 3 and Physics II 3. Under the term movement Aristotle subsumes quantitative change, qualitative change and change of place. These processes, not only in living beings, but generally in nature, are guided by internal finality. Matter has no own existence without any form. Matter - Aristotle founded the term hyle to meet this relationship - belongs to the side of pure possibility (dynamis) or the potential being (dynamei on), whereas form is the realization (energeia/entelecheia) or the actual being (energeia on). Matter for Aristotle is "a something of mere possibility".
} 
reproduction or of memory. The unconscious memory, he said, steered the characteristic movements of the molecules to produce a ramified undulation. According to him, all reproductive energy was the result of a function of the atomic composition of the plastidule and its specificity was based on the phylogenetic memory of each individual plastidule. By proposing an historical category for the heredity units he supposed theoretically, Haeckel points out the problem of activating dispositions (Anlagen) that had to fulfill a predefined process over a given period of time even in the early years of biology. Haeckel demands a basic law of ontogenesis: "(T)he ontogenetic division of labor in cells [...] is but the quick repetition of the slow process of phylogenetic tissue generation according to the basic law of biogenetics." (1876, 49. Italics in the original).

Darwin and Haeckel assumed hereditary capacities that they located in the powers of atoms or molecules. Carl Wilhelm Nägeli (1817-1891) rejects such assumptions. He claims that Darwin and Haeckel's belief that the organizing powers of heredity had their place in individual atoms and molecules was based on the still young concept of atoms. He explains that, instead, an organized combination of molecules was what caused it. Nägeli suggests presuming a substance that is capable of determining the numerous features of organisms simply by changing the disposition of a limited number of elements:

In order to understand heredity, we do not need an independent specific symbol for every variation caused by a different time, place or characteristic, but rather a substance that can represent any possible combination of differences through a certain composition of its limited number of elements and that can pass from one such combination to another by permutation. $(1884,69-70)$.

Nägeli explains that this claim was fulfilled by idioplasmatic anlagen and goes on to describe its hypothetical makeup in all detail. His speculative theory already requires some genetic material that can represent and produce all necessary components of living creatures only by permutation of a limited number of elements. It was precisely this conceptual goal that was later met by the introduction of the model of four interchangeable bases within triplets of bases to biology in 1953 .

Nägeli's version is a purely theoretical description of a heredity substance that was to contain "the essence of the invisible anlage for the visible appearance of the developed state located within the organized living substance" $(1884,19)$. 
Nägeli imagined this substance to be an anlageplasma that consisted of albumins and called it an idioplasm. He further said that its molecules were deposited next to one another in crystal-like groups, micella, only some of which were "real" anlagen and could thus reproduce the patterns of the micella and their differing configurations by means of modifications of the albumins in the offspring. In his view, the micella represented the macrocosm of organs, tissue and cells in microscopic form and without an analogous disposition. By supposing a substance that is solely specialized on inheritance, Nägeli anticipated Johannsen's differentiation between genotype and phenotype. His hypothesis of micella being arranged like pearls on a string can be seen as an early use of the principle of the linear array of DNA bases, whose permutability ensures the specificity of the genetic code.

In the philosophy of science, the premise for such a conception lies in the focus on a micro region in the examination of the development of a new living being. The mechanics of organic life would not be composed of mass movements but of movements of the smallest particles. So the science of heredity would have to enter the molecular-physiological field in order to reach congruence with the chemical and physical laws of nature. "It is only in the idioplasmatic anlagen that the complete essence of the organism is contained" $(1884,275)$.

The same is nowadays expected from the gene. However, in contrast to the modern view and in spite of all his materialistic reduction, Nägeli maintained that Darwin's theory of utility needed to be complemented by a principle of perfection $(1865,27)$.

August Weismann (1834-1914) also called for a substance that was independent from the remaining substances of the organism and specialized on the transmission of hereditary traits. He draws on Haeckel's concept of a phylogenetic memory to define the traits of hereditary plasma and its separate units. In his view, heredity was based on the continuity of germ molecules and consisted in a transgenerational germline made of germ-plasm, which he also calls ancestral plasm. He further explains that it is made up of subunits that must not be confused with the smallest particles of life like Spencer's physiological units nor with pangenes and gemmulae according to Darwin. After all, he said, they were neither produced in the somatic cells nor gathered in the reproductive cells; germ-plasm was rather "a substance that was precisely meant for this" (1892b, XII). A new name had to be found for the "primary forces of life": "bearers of vitality" (Lebensträger) or "biophors" (Biophoren) (1892b, 52-53). He elaborated that the architecture of this germ-plasm had been transmitted historically and that the vital units were hierarchized. According to Weismann, several biophors formed determinants, which in turn were also organized in groups - "ids" - in reference to 
Nägeli's idioplasm - that split into identical daughter-ids for the purposes of reproduction and development. Weismann already acknowledged a principle of identical duplication (1892b, 82-95).

He also explains that selection did not occur between fully fledged individuals, but rather between stronger and weaker "dispositions" (Anlagen) in the germs, between dispositions for outward features hidden in the germ-cells (1892b, 96. Weismann here quotes 1892a). Early in the history of the selection-hypothesis, he took up a definite position by this description on the question that persistently in the $20^{\text {th }}$ century should build an unsolved problem: Does selection choose among individuals or among the material carriers of heredity, the genes? With his evolutionary contest of heredity particles, Weismann preempts a concept that in 1976 Richard Dawkins $\left({ }^{*} 1941\right)$ was to elaborate on with his competition among genes. Dawkins calls the gene a replicator. He also gives an answer to the question about the unit of selection. The fundamental unit of selection would not be the species, nor the group nor even strictly individual, but only the gene. But otherwise selection would not work on genes directly (1976).

The introduction of causes of hereditary traits that are distributed between particles and that appear to contain a historical memory of phylogenesis, which emerges step by step during ontogenesis, gave rise to the issue of how and by what means parts of this memory were activated and how the timing was controlled. Carl Weigert (18451904) proposed an idioplastic power. He claimed that the anlage in the nucleus could not possess the final qualities. What was stored there were rather "just the dispositions for dispositions, or even for the dispositions for dispositions" $(1887,103)$. As Weigert explains, dispositions were growth tendencies. Tendencies would not exist really, rather they existed potentially in the hereditary substance. They had different amounts of energy, an "idioplasmatic" power of getting unfolded.

The theory of idioplasm as a separate substance of the inheritance processes requires a distinct set of principles of heredity, which had to be the same for the entirety of organic beings. The structuring into cells was uncontested as a universal principle of plants and higher life forms. Hugo Marie De Vries (1848-1935) consistently applied this principle to Darwin's provisional hypothesis of pangenesis. He came to the conclusion that not organisms, but rather cells were the units of a theory of heredity. He explained that every species was made up of individual factors, i.e. hereditary characters or anlagen, and that these units had, as independent substances, developed at different times. He further described them as independent from one another, able of being mixed together in any proportion, and says 
that each of them can be pronounced to different degrees or be lost individually (1889, 31-33). De Vries called them pangenes. Like Darwin, he believed them to be capable of assimilation, nutrition, metabolism and fission. However, he also said that they only circulated within the cell. Activated pangenes, he claimed, left the nucleus for the cell organelles, united there "with the pangenes that are already present, multiply, and begin their activity" (1889, 211-212). During the division of the cells "all the different kinds of pangenes are evenly distributed over the two daughter-cells" $(1889,73)$. All kinds of pangenes of the respective species are represented in the nucleus, "the remaining protoplasm in every cell contains chiefly only those that are to become active in it" $(1889,195) .^{7}$ From today's point of view, mRNA, tRNA, rRNA also circulate intracellularly.

Wilhelm Johann Haacke (1855-1912) rejected such immediate transmission of morphological influences and proposed a dynamic form of transmission that did not have its origins in material pangenes. As a consequence of the dynamics of the transmission of hereditary traits, he explained, the agents of heredity units are located in the protoplasm, not the nucleus. The plasma of egg cells, he said, was made up of "individuals", "gemmaria" (Gemmarien) of a fixed shape, in sum made up of diamond-shaped "gemmae" (Gemmen). He differs from Darwin by saying that it was not the smallest units that carried hereditary and acquired characteristics, but rather larger entities $(1893,119)$.

Gregor Johann Mendel had chosen a completely different approach. He did not enter into speculations about the nature of hereditary material, but developed an experimental system in order to statistically examine the occurrence and disappearance of certain traits in the garden pea Pisa sativum from one generation to the next. He drew the following conclusion from his experiments in hybridization: "The differentiating characters of two plants can finally, however, only depend upon differences in the composition and grouping of the elements which exist in the foundation-cells of the same in vital interaction." (Bateson 1902, 89-90).

In his translation of Mendel's work William Bateson, in 1902, uses the term "composition and grouping of the elements". Mendel, when explaining the internal

\footnotetext{
7 The features of the intracellularly circulating pangenes, as De Vries describes them, nevertheless remind in many points of Darwin's gemmules which would circulate throughout the whole body. But they differ in another important point. Although a pangene would consist of innumerous molecules, it did not work in a simple chemical manner. Its effectiveness is of another level as that of chemical molecules.
} 
causes for the external characters by hypothetical elements inside of the germ cells, also uses such an expression. Concerning the development of the plant and its law, he names the composition and arrangement of the elements to be the determining law: "This development follows a constant law, which is founded on the material composition and arrangement of the elements which meet in the cell in a vivifying union" (Bateson 1902, p. 88). ${ }^{8}$

So basic reasons for this kind of determination by inheritance must lie in the following:

1. material characteristics of biological elements, the material composition,

2. their arrangement.

By holding the arrangement and material composition of internal elements accountable for their effects, Mendel early on presented a view, which would later also be developed in the speculative theories of Weismann, Nägeli and the other scientists of this epoch. Those principles became characteristic of the modern conception of genes, which are effective through the inheritable arrangement of their structure, the order of whose elements defines body features. At this point in the course of history, a close proximity and coherence can already be found: In the terminology described above, the $19^{\text {th }}$ century anticipated attributes of the term "gene" as it was later developed. Through mutual examination, it prepared the future conception of the term in many details.

\section{Specification of the terminology with the help of experiments}

It was on this basis that Wilhelm Johannsen (1857-1927), professor of botany in Copenhagen, in 1903 suggested a term for the heredity units in question in a lecture, aiming to be very restrictive about its content:

\footnotetext{
${ }^{8}$ In his formalism Mendel does not follow a pure materialistic way of description. It remains important for him to correlate his terms with the sphere of vividness. The supposed elements stand in "vital interaction", or rather, they "meet in a vivifying union". Later this reference, originating from Aristotle's biological question - where does the vividness of the living come from? -, disappeared. For Hans Kalmus Mendel's concept of the opposite dominance-recessivity traces back to Aristotle's distinction dynamis-energeia, thus reflecting the Aristotelian idea on substance $(1983,67)$.
} 
(I)t is only meant to express the simple idea that there is "something" in the gametes that causes, codetermines or can codetermine characteristics of the developing organism. It is not intended to propose or support any hypothesis about the nature of this "something". This is why it appears easiest to use the last syllable "gene" from DARWIN's well-known term alone, which is all that matters to us; it shall replace the improper word "anlage". (1909, 124).

So he discarded the syllable pan from pangene, which left him with gene. He continued: This term, which is "completely free" from any hypothesis, denoted only:

the proven fact that at least many characteristics of organisms are conditioned by specific, separable and thus independent "states", "foundations", "anlagen" - for short, what we will henceforth call g e n e. (Ibid.; spaced type in the original in the German language).

Johannsen objected to a conceptual character of the model. At the same time, he stressed that another advantage of the term gene was that it could more easily be combined with other expressions. He gives the example that instead of "the gene that conditions the trait" it could now be said "the gene of the trait". But it is precisely this expression that makes us overlook the fact that traits only are conditioned by genes and which in turn gives the impression it was a unilinear and strict causal relationship, - a perception which should be kept for decades.

In the same lecture, Johannsen introduced two other terms that, later in the history of biology, also gained lasting significance: genotype and phenotype. In 1911, he consistently defined heredity as "the presence of identical genes in ancestors and descendants" $(1911,159)$. Due to his differentiation between genotype and phenotype, the search for the genetic activity of underlying units could be conducted without having to allow for the requirements of time regulations during the development and processes within the cells. The newly emerged branch of science of genetics had gained a new sphere of understanding for new laws to be comprehended that were already given in abstraction. This made insights with great explanatory power possible that had 
been gained in empirical and experimental studies and that appeared to be supported by a - newly established - abstract principle "gene", the paradigm for genetics.

In 1916, Thomas Hunt Morgan (1866-1945) and Calvin Blackman Bridges (1899-1938) declared that the gene was mutable:

On a priori grounds there is no reason why several mutative changes might not take place in the same locus of a chromosome. If we think of a chromosome as made up of a chain of chemical particles, there may be a number of possible recombinations or rearrangements within each particle. Any change might make a difference in the end-product of the activity of the cell, and give rise to a new mutant type. $(1916,13)$.

What was ascribed to plasm in the $19^{\text {th }}$ century, appeared to have been found now in individual material units, units of heredity that were no longer postulated speculatively, but seemed to have a permanent place where they could be clearly localized. "The germ plasm must, therefore, be made up of independent elements of some kind. It is these elements that we call genetic factors or more briefly genes" (1917, 515). As Morgan discovered, in crossing experiments of the vinegar fly Drosophila melanogaster, that certain new characters like eye color and form of the wings occurred together regularly, he concluded there must be a linkage of genes: linked hereditary factors. He took this as an indication that Mendel's factors were present as chemical substances in the polytene chromosomes of Drosophila. He discovered a linear order of the genes, linkage groups and their connections as well as the boundaries of these groups of genes. His pupil Bridges was able to show that irregularities in sex-linked heredity were caused by faults in the division of chromosomes, more evidence for the theory of the gene: "Nondisjunction as Proof of the Chromosome Theory of Heredity" $(1916,161)$.

Now the theory of the gene was given a new description in the Chromosome Theory of Heredity:

1. Chromosomes are the material carriers of genes.

2. Every gene has its precise position on the chromosome.

3. Linked genes are passed on together.

4. A crossing-over, chromatids, the products of the longitudinal separation of 
chromosomes, partly crossing with break-up at the points of contact and an exchange of pieces, can lead to an exchange of genes between the chromosomes involved: mutation.

So far the presencelabsence hypothesis had been in place: A gene was either present or it did not exist in the entirety of the genes of an organism. Alfred Henry Sturtevant (1891-1970) replaced this hypothesis with a theory of multiple alleles according to which it was the interaction of several groups of homologous genes that caused the expression of a characteristic. He also detected a position effect for individual genes (1925, 136-139). In this technique of identification, a unit is only proven to be a gene when it is no further divisible by means of translocation due to spontaneous or artificial chromosomal breaks by recombination.

Experimenting with the gametes of fruit flies, Hermann Joseph Muller (18901967) found that mutations can systematically be induced with the help of $\mathrm{X}$-radiation. He believed that the physical materiality of the gene was proven with this kind of physical determinability. Thus, he explained, genetic physiology became closer to some genetic physics and genetic chemistry (1927, 85, 87). Muller had detected that X-rays produced changes of the same kind as the gene mutations obtained without such treatment. This would legitimate the new subject of gene physiology and at least of gene physics and gene chemistry.

Under these conditions, a final causality appeared to be ruled out definitively for the biological gene, even despite its peculiarity. Precisely this had been one of Darwin's main objectives when he constructed the hypothesis of evolution. After genes had become the basic substance of a materialistic theory of heredity, the assumptions about mechanical forces that could be located in space needed to be reconciled with this doctrine. Now - quite late - this problem appeared to be solved.

The classical concept of the gene defines it as a segmental unit that behaves coherently in mutation and crossing-over. It is thought to control the growth of the organism and the development of body features. It is said to be self-selective and to be transmitted from cell to cell in duplicates or from ancestors to progeny through gametes. The source of new genes is seen in new arrangements in the order of the segmental units. The gene in this conception corresponds in many details to the notions developed by Nägeli, Weismann and the other scientist of that time.

Two new aspects had been added to the term "gene":

1. Self-reproductivity: the capacity to effect the build-up of a structure that is the 
same as its own. The daughter-gene contains copies of mutations of its own predecessor gene, based on the unexplained ability to take components that are akin to its own constituents from a heterogeneous environment and link them to itself.

2. Self-selectivity. A gene tends to link with genes that have the same structure as itself.

A constant adversary of the theory believing in locatable particles was Richard Benedikt Goldschmidt (1878-1958), who kept reminding his colleagues that the dynamics of the organism as a whole had to be taken into account in every process of heredity. He explained that turning to hereditary units was a by far too static view for embracing the dynamic, processual aspects and the courses of movement in material differentiation when it came to understanding the development of the organized structures over the course of time $(1927,1938)$. However, from a chemical and physical perspective, a description in chemical terms seemed to be more important in the search for the genetic principle in order to satisfy the laws of physics as well as explain the biological specificity of self-reproduction. The substance of the genetic material was sought in protein. So in 1939, Sturtevant and George Wells Beadle (1903-1989), associates of Morgan's, thought it was a "reasonable supposition" that genes were either proteins themselves or at least associated with them $(1988,335$, here quoting 1939). But the authors emphasize that their supposition could not be based on facts about the nature of genes but only on another assumption concerning the role of genes. Either genes themselves or immediate products of gene activity took part in developmental reactions.

The atomic physicist Erwin Schrödinger (1887-1961) felt there were physical laws of an entirely new kind at work because the structure of the gene was different from anything that had ever been examined in a physical laboratory and he expected the analysis of the gene to reveal new laws for physics as a whole. The reason he gave was that the active substrates of genetics held the creative as well as the executive power. Schrödinger proposed terminology from communications technology to understand how the living substance of the genes was able to contain the blueprint as well as the capacity for implementing it, to store its experience and pass it on, to perpetuate it and, at the same time, to change itself $(1967,139)$. He explained that a code mechanism met the conditions required from the gene because it allowed for consistency in characteristics through unchanged multiplication of the gene in the 
reproduction process and, at the same time, offered the opposite possibility of variation that also enabled changes in characteristics.

Once more, the resolution for contradictions in the modern conception of matter that before seemed irreconcilable lay in the notion of the gene. The abstraction of this question that was found was not based on the chemical and physical principles of energetics and atomic theory only. It originated from the - speculatively developed - attributes of the biological preconception of some particulate hereditary plasma as the substrate of what contained the cause of the development of the species and characteristics, the description of the biology of the $19^{\text {th }}$ century.

The question about the materiality of the gene within the chromosome now had to explain how a chemical basis could determine the specificity of biological functions, and, consequently, a biochemical formulation lead to this aim.

In 1936 Linus Carl Pauling (1901-1994) was one of the scientists who detected a special type of molecular bond for protein as the fundamental biochemical substance of carbon chemistry: the hydrogen bridge. "Connections between hydrogen atoms with only weak bonding forces determine the protein configuration" (Mirsky \& Pauling 1936, 442). This type of bond seemed to perform the biological specificity of proteins. Four years later, in his book The Nature of the Chemical Bond, Pauling stresses the general importance of the hydrogen-type of bond in biology:

I have little doubt that in this field resonance and the hydrogen bond are of great significance [...]. A conjugated system provides the only way of transmitting an effect from one end to another of a long molecule; and the hydrogen bond is the only strong and directed intermolecular interaction which can come into operation quickly. (Pauling 1940, 431).

\footnotetext{
${ }_{9}$ But Schrödinger, as Kay explains, did not use terms like information, program, alphabet, word, message or text to explain genetic processes. In genetics, such expressions not would have gotten common before the mid 1950s. Of particular impact would have been the introduction of the term cybernetics by Norbert Wiener who in 1948 presented his theory Cybernetics or Control and Communication in the Animal and the Machine.
} 
In 1940 the principle of chemical bonding that 13 years later became significant for the hereditary substance in the form of double stranded nucleic acids had been found: "To give stability to a system with complementary structures in juxta-position" (Pauling \& Delbrück 1940, 77). This was why Pauling and Max Ludwig Henning Delbrück (1906-1981) emphasized: "We accordingly feel that complimentariness should be given primary consideration in the discussion of the specific attraction between molecules and the enzymatic synthesis of molecules" $(1940,78)$.

The principle of complementarity manifested itself in the DNA model of complementary bases in 1953 .

In 1936, Torbjörn Caspersson (1910-1997) and his colleagues discovered pentose nucleic acid in the bands of polytene chromosomes in the salivary glands of Drosophila flies and, two years later, in collaboration with Rudolf Signer (1903-1990) and Einar Hammarsten (1889-1968), was found that the analysis of this acid was a possible way of finding out more about the structure of chromosomes. They already suggested that the bases were arranged vertically to the axis of the molecule (Signer et al. 1938, 122), one of the basic construction principles of the later DNA. Caspersson and Jack Schultz (1904-1971) observed that there could be a connection between the make-up of the nucleic acids and the reproduction of the genes. "It seems hence that the unique structure conditioning actively self-reproduction [...] may depend on the nucleic acid portion of the molecule" $(1938,295)$. Yet they still believed that it was the quality of the proteins that caused their multiplication and also the synthesis of the nucleic acids.

It was the year 1944 that brought the turning point. While transforming the cell walls of pneumococci, Oswald Theodore Avery (1877-1955), Colin Munro MacLeod (1909-1972) and Maclyn Mc Carty (1911-2005) discovered that the transforming principle must be in the nucleic acid $(1944,156)$. After the Second World War Beadle explored metabolic diseases. For the metabolic pathway of methionine, he found that the genetic activity consisted in the regulation of individual chemical reactions in a chain of reactions. In addition to that, he compared the wavelength of UV light when it caused mutations with its absorption spectrum for nucleic acid in experiments. He came to the conclusion: "nucleic acid is the component responsible for absorbing the energy producing mutational changes" $(1946,52)$. In 1948, he declared that the classical definition of the gene as a hereditary unit was insufficient. It had been found, he explained, that individual genes had immediate control over certain reaction steps in a series of chemical reaction processes. This was why he proposed a new provisional definition: 
1. From a functional point of view, a gene is a unit that regulates the synthesis of duplicates of itself.

2. With a specificity corresponding to it, this unit also serves as a model for nongene sequences.

He named the production of the amino acid methionine by the bread mold Neurospora crassa as an example of a process of synthesis that was successively controlled by genes $(1948,69-74)$. In 1952, Alfred Day Hershey (1908-1997) and Martha Chase (1927-2003) introduced bacteriophages into the bacterium Escherichia coli and afterwards examined protein and nucleic acid as to what influenced the ensuing life cycle of the virus. They discovered that the virus was governed by its DNA. The protein, they claimed, had no function in the multiplication of the phage $(1952,54)$.

The sought biochemical model, which needed to display the features required for a hereditary substance according to the findings from experiments, had to be a structural model of DNA. It was described to its last details in 1953 by Watson and Crick, Franklin and Wilkins.

It was said that the absolute biological principle consisted in the identical reduplication of the gene, in its capacity to produce an exact copy of itself during the splicing of the cell when the number of chromosomes was doubled. The model deduced a biological consequence from given chemical conditions. The mechanism for the self-duplication of the hereditary substance was the result of the predetermined chemical possibilities for the pairing of the bases and the fact that hence the array of the new nucleotide sequence was determined by the old sequence (Watson/Crick 1953b, 966).

The repeated conditional form in the train of thoughts, which had developed the details of the structural formula from the attributes of the gene that had been found through speculation before, was substantiated with the help of chemical laws that in their turn had been incomplete and that were further developed as the model was conceived. The biological process of gene duplication during cell division and protein synthesis includes a newly found chemical law. Watson and Crick drew conclusions concerning the notion of the gene from their model: DNA is the genetic specificity of the gene itself (1953b, 964). The genetic principle causes the biological specificity of the chemical substance. Genetic activity is located in the patterns of complementary pairs of bases in a nucleic acid, one half of which is produced in accordance with the other that is its opposite. The gene's efficient causality refers to its chemical qualities. The chemistry of the gene is the reason for the specificity of organic substances. The sequence 
of bases is the decisive principle in the heredity substance. As statistically there are innumerable possible arrangements, the material cause of a being's individuality, or rather the composition of the substances of this cause, is regarded as random when it is first formed, the consequence of a history of mutations. The developmental processes that follow in the growing organism, with the exception of environmental influences with the status of marginal conditions, are to the largest extent strictly determined.

In the 1930s, Muller had postulated that the gene's capacity of maintaining its identity by itself was its essential feature. The model of the gene as proposed by Crick and Watson interprets the hypothesis of a self-reproduction of biological material in biochemical terms. Now a mechanistic description of how a chromosome could be identically duplicated without the daughter cell containing the same material had become possible. It is only the same in a formulaic way, where matter is concerned it is the same kind: identical duplication. Two types of causes, causa formalis as well as causa materialis, are accounted for. Rated as causa efficiens are the evolutionary driving forces in the processes of reproduction, species and self-preservation, propagation, drive, instinct. It is only the causa finalis that is suspected of anthropomorphism. And from that the problem arises: Does this kind of causality concept adopt final elements from previous modes of conception? Were there hidden anthropo-morphisms at the base of the notion that was conceived in the wake of an understanding of the gene within evolutionary theory, which were to be avoided with the help of Darwin's theory of heredity?

\section{Conclusions about the attributes that make up the term}

The gene is conceived as a unit that controls the synthesis of replicas of itself, be it as a redundant system of development or under an epigenetic influence. This does not just reflect the conceptions of developed Mendelism or classical genetics. Kant had proposed it as early as in the $18^{\text {th }}$ century in the term natural purpose. However, he had also pointed out that self-organization and self-reproduction could not be imagined without a final causality when it was referring to living organisms. At the beginning of the historical line of thought, the "self" had been identified as the characteristic feature of a hypothetically assumed genetic substance. In reaction to the philosophy of nature, theoretical treatises used the terminology of mechanics to describe it. Meanwhile, they all - whether it was Spencer's physiological units, Darwin's gemmules, Nägeli's idioplasm, Weismann's biophores and determinants or De Vries' pangenes acted as factors that brought final structures into being with the help of some material that was inherent to the substance, still unknown, pre-structured and 
believed to be memory-like and that developed successively while the organism was growing after it had been transmitted in a hereditary process. With the use of the term "factor", heredity becomes an action. It is caused by something memory-like. It $r$ e presents a history of changes that the transmitting factor and the type of the being in question have experienced in the course of their history. In a modern perspective, the passage of material units is described in terms of scientific semantics, grammar and communication theory, not by way of an analogy but as a reality that is deemed imperative and that enabled this theory about such a special material of life. This characterization is no longer a simple hypothesis. The difference between biological evolution and cultural development was "biologicized" and was to be explained on the grounds of biological theory. Is it thus explained away? What anthropomorphisms are hiddenly contained in these biological explanations? The problem arises that it might be impossible to abstain from them as long as terms like cause, reason and matter are used that are all derived from human self-experience, just like the terms self and memory. With the attributes "self" as in "self-reproductivity" and "self-selectivity", and "memory" as in "phylogenetic memory" or "code" as in "genetic code", the term "gene" still reflects the notions of natural purpose and an end in itself. The early scientific history, on the basis of those inclusions in the scope of the term "gene" as it was developed in the $19^{\text {th }}$ century, introduced the idea of a specialized heredity substance whose particulate sub-units caused the transmission of body features over generations. According to the objective of the abstraction and the technical terms introduced for this purpose, the mode of operation of those units is described in mechanistic terms. On the other hand, it is represented in a code-like memory. The new logical species contains attributes of genera that were unconnected before. It is because of this that the "biological" characteristics described thus still contain anthropomorphic specifications. They are early components of the future term "gene".

\section{References}

Avery, Oswald [Theodore]; MACLEOD, Colin [Munro]; Mccarty, Maclyn (1944). "Studies on the chemical nature of the substance inducing transformation of pneumococcal types". The Journal of Experimental Medicine Vol. 79/2, 137-158.

BATESON, William (1907). "The progress of genetic research. An inaugural address to the third conference on hybridization and plant-breeding". Report of the Third International Conference 1906 on Genetics; hybridization (the cross-breeding of genera 
or species), the cross-breeding of varieties, and general plant-breeding. Ed. Wilks, W. London: Royal Horticultural Society Spottiswoode \& Co. LTD.

-(1902). Mendel's principles of heredity. A defence. With a translation of Mendel's original papers on hybridization. Cambridge: Cambridge University Press.

BeAdLE, G[eorge] W[ells] (1948). "Genes and biological enigmas". American Scientist 36/1, 69-74.

-(1946). "Genes and the chemistry of the organism". American Scienctist 34/1, 31-53, 76.

BRIDGES, Calvin B[lackman] (1916). "Non-disjunction as proof of the chromosome theory of heredity". Genetics 1, 1-52, 107-163.

Carlson, Elof Axel (1966). The Gene: A Critical History. Philadelphia: W. B. Saunders Company. Cf. the same author in the german language (1971). Gentheorie. Stuttgart: Fischer.

Caspersson, T[orbjörn]; Schultz, Jack (1938). "Nucleic Acid Metabolism of the Chromosomes in Relation to Gene Reproduction". Nature 142/3589, 294-295.

CORRENS, C[arl Erich Franz Joseph] (1912). Die neuen Vererbungsgesetze. Nach einem Vortrag gehalten am 13. Dezember 1911 vor dem Wissenschaftlichen Verein in Berlin. Berlin: Gebrü-der Borntraeger.

-(1905).“Gregor Mendels Briefe an Carl Nägeli 1866-1873. Ein Nachtrag zu den veröffentlichten Bastardierungsversuchen Mendels". Abhandlungen der Königlich-Sächsischen Gesellschaft der Wissenschaften. Math.-Phys. Classe, Vol. 29, 187-265.

-(1900). "G. MendeL's Regel über das Verhalten der Nachkommenschaft der Rassenbastarde". Berichte der Deutschen Botanischen Gesellschaft Vol. 18, pp. 158168.

CREMER, Thomas (1985). Von der Zellenlehre zur Chromosomentheorie. Naturwissenschaftliche Erkenntnis und Theorienwechsel in der frühen Zell- und Vererbungsforschung. (Veröffentlichung der Forschungsstelle für Theoretische Pathologie der Heidelberger Akademie der Wissenschaften). Berlin: Springer.

DARDEN, Lindley (1991). Theory Change in Science. Strategies from Mendelian Genetics. New York: Oxford University Press.

DARWIN, Charles [Robert] (1968). The Variation of Animals and Plants under Domestication. Vol. 2. London: John Murray.

Dawkins, Richard (1976). The Selfish Gene. Oxford: Oxford University Press.

Dunn, L[eslie] C[larance] (1965). A short history of genetics. The development of the main lines of thought 1864-1939. New York: MacGraw-Hill. 
Frankuin, R[osalind] E[1sie]; GosLIng, R[aymond] G. (1953): "Molecular Configuration in Sodium Thymonucleate". Nature 171/4356, 740-741.

Goldschmidt, Richard [Benedict] (1938). "The theory of the gene". The Scientific Monthly 46/3, 268-273.

(1927). Physiologische Theorie der Vererbung. Berlin: Springer.

HAACKE, Wilhelm (1893). Gestaltung und Vererbung. Eine Entwicklungsmechanik der Organismen. Leipzig: Weigel.

Haeckel, Ernst (1876). Die Perigenesis der Plastidule oder die Wellenerzeugung der Lebenstheil-chen. Ein Versuch zur mechanischen Erklärung der Entwicklungs-Vorgänge. Berlin: G. Reimer.

Hegel, Georg Wilhelm Friedrich (2000). Gesammelte Werke. In Verbindung mit der Deutschen Forschungsgemeinschaft herausgegeben von der Nordrhein-Westfälischen Akademie der Wis-senschaften. Vol. 13. Enzyklopädie der philosophischen Wissenschaften im Grundrisse. (1817). Eds. Bonsiepen, Wolfgang; Grotsch, Klaus. Hamburg: Meiner.

-(1992). Gesammelte Werke. In Verbindung mit der Deutschen Forschungsgemeinschaft he-rausgegeben von der Rheinisch-Westfälischen Akademie der Wissenschaften. Vol. 20. Enzyklopädie der philosophischen Wissenschaften im Grundrisse. (1830). Eds. Bonsiepen, Wolfgang; Lucas, Hans-Christian. Hamburg: Meiner.

Hershey, A[lfred] D.; ChASE, Martha (1952). "Independent functions of viral protein and nucleic acid in growth of bacteriophage". The Journal of General Physiology 36, $39-56$.

Hoppe, Brigitte (1978). "Umbildungen der Forschung in der Biologie im 19. Jahrhundert". Konzeption und Begriff der Forschung in den Wissenschaften des 19. Jahrhunderts. Ed. Diemer, Alwin. Meisenheim am Glan: Hain.

JOHANNSEN, Wilhelm (1911). "The genotype conception of heredity". The American Naturalist 45/531, 129-159.

-(1909). Elemente der exakten Erblichkeitslehre. Deutsche wesentlich erweiterte Ausgabe in fünf-undzwanzig Vorlesungen. Jena: Fischer

-(1905). Arvelighedslaerens elementer. Forelaesninger holdte ved Kobenhavns Universitet Arve-lighedslaerens elementer. Kobenhavn: Gyldendalske Boghandel, Nordisc Forlag.

Johansson, Ivar (1988). Meilensteine der Genetik. Eine Einführung - dargestellt an den Entde-ckungen ihrer bedeutenden Forscher. Berlin: Paul Parey.

Kalmus, Hans (1983). "The Scholastic Origins of Mendel's Concepts". History of Science 21, 61-83.

ÉNDOXA: Series Filosóficas, n. 40, 2017, pp. 103 - 133. UNED, Madrid 
Kant, Immanuel (2000). Critique of the power of judgement. Translated by Paul Guyer and Eric Matthews. Ed. Guyer, Paul. Cambridge: Cambridge University Press.

KaY, Lily E. (2000). Who Wrote the Book of Life? A History of the Genetic Code. Stanford: Stanford University Press.

Keller, Evelyn Fox (2000). The Century of the Gene. Cambridge (Mass.): Stanford University Press.

Krumbiegel, Ingo (1957). Gregor Mendel und das Schicksal seiner Entdeckung. Stuttgart: Wissenschaftliche Verlagsgesellschaft.

Mendel Gregor [Johann] (1866). "Versuche über Pflanzen-Hybriden. Von Gregor Mendel". Vorgelegt in den Sitzungen vom 8. Februar und 8. März 1865. Verhandlungen des natur-forschenden Vereins in Brünn. Vol. IV. 1865, Abhandlungen. Brünn 1866: by the association's publishing house, 3-47.

Mirsky, Alfred; PAuling, Linus [Carl] (1936). "On the Structure of Native, Denatured and Coagulated Proteins". Proceedings of the National Academy of Science 22/7, 439-447.

Morgan, Thomas Hunt (1917). "The theory of the gene". The American Naturalist 51/609, 513-544.

Morgan, [Thomas Hunt]; Bridges, [Calvin Blackman] (1916). "Sexlinked Inheritance in Drosophila by T. H. Morgan \& C. B. Bridges". Carnegie Institute of Washington Publication No. 237. Ed. Carnegie Institution of Washington. Washington: Gibson Brothers.

Moss, Lenny (2003). What Genes Can `t Do. Cambridge (Massachusetts): MIT Press.

Muller, H[ermann] J[oseph] (1927): "Artificial Transmutation of the Gene". Science 66/1699, 84-87.

NÄGELLI, C[arl] [Wilhelm] v[on] (1884). Mechanisch-physiologische Theorie der Abstammungslehre. Leipzig: R. Oldenburg.

(1865). Entstehung und Begriff der Naturhistorischen Art. Rede in der öffentlichen Sitzu$n g$ der $k$. Akademie der Wissenschaften am 28. März 1865 zur Feier ihres einhundert und sechsten Stiftungstages gehalten von Dr. Carl Nägeli, $k$. Universitäts-Professor und ordentliches Mitglied der Akademie. München: Verlag der königl. Akademie.

Olby, Robert C[ecil] (1974). The Path of the Double Helix. Seattle: University of Washington Press.

PAULING, Linus [Carl] (1940). The nature of the chemical bond and the structure of molecules and crystals: an introduction to modern structural chemistry. London: Oxford University Press.

Pauling, Linus [Carl]; DelbrüK, Max [Ludwig Henning] (1940). "The nature of the intermo-lecular forces operating in biochemical processes". Science 92/2378, 77-79. 
Rheinberger, Hans-Jörg; Müller-Wille, Staffan (Eds.) (2009). Vererbung. Geschichte und Kultur eines biologischen Konzepts. Frankfurt: Fischer.

Rivera de Rosales Chacón, Jacinto (2017). "Versuch einer Auslegung der Kantischen teleologischen Dialektik". Vortrag gehalten auf der Internationalen Tagung: Teleologische Reflexion in Kants Philosophie, Heidelberg am 11.02.2017

SCHRÖDINGER, Erwin (1967) [1944]: What is Life? With Mind and Matter and Autobiographical Sketches. The Physical Aspect of the Living Cell. Cambridge: Cambridge University Press. (Reprint of: What is Life? The Physical Aspect of the Living Cell. Based on Lectures Delivered under the Auspices of the Dublin Institute for Advanced Studies at Trinity College, Dublin, in February 1943. Cambridge: Cambridge University Press 1944).

Signer, R.; Caspersson, T[orbjörn]; Hammarsten, E[inar] (1938). "Molecular Shape and Size of Thymonucleic Acid". Nature 141/3559, 122.

Spencer, Herbert (1864). A System of Synthetic Philosophy. Vol. II. The Principles of Biology. Vol. I. The Principles of Biology. By Herbert Spencer. London: Williams and Norgate.

Sturtevant, A[lfred] H[enry] (1925). "The effects of unequal crossing over at the bar locus in Drosophila”. Genetics 10, 117-147

(1913). "The linear arrangement of six sex-linked factors in Drosophila, as shown by their mode of association". Journal of Experimental Zoology 14, 43-59.

Sturtevant, Alfred Henry; Beadle, George Wells (1988) [1939]. Genes, Cells and Organisms. Great Books in Experimental Biology. Vol. 6. An Introduction to Genetics. Ed. Moore, J. A. London: Garland. (Reprint of the 1939 edition).

TReviranus, [Gottfried] Reinhold (1802). Biologie, oder Philosophie der lebenden Natur für Naturforscher und Aerzte. Vol. 1. Göttingen: Johann Friedrich Röwe.

Tschermak [- SeysenegG], E[rich] [von] (1900): "Über künstliche Kreuzung bei Pisum sativum. Berichte der Deutschen Botanischen Gesellschaft 18, 232-239.

[DE] VRIES, H[ugo] [Marie] (1900). „Das Spaltungsgesetz der Bastarde: vorläufige Mittheilung". Berichte der Deutschen Botanischen Gesellschaft 18, 83-90.

-(1889). Intrazelluläre Pangenesis. Jena: Fischer.

Wallace, Bruce (1992). The Search for the Gene. Ithaca: Cornell University Press.

Watson, J[ames] D[ewey]; CRICK, F[rancis] H[arry] C[ompton] (1953a). "Molecular Structure of Nucleic Acids. A Structure for Deoxyribose Nucleic Acid". Nature 171/4356, 737-738.

-(1953b). "Genetical Implications of the Structure of Deoxyribonucleic Acid". Nature 171/4361, 964-967.

ÉNDOXA: Series Filosóficas, n. 40, 2017, pp. 103 - 133. UNED, Madrid 
WeIGERT, C[arl] (1887). "Neuere Vererbungstheorien". Schmidt's Jahrbücher der Inund Ausländi-schen Gesammten Medizin 215, 89-104, 192-206.

WeISMANn, August (1892a). Aufsätze über Vererbung und verwandte biologische Fragen. Jena: Fischer

-(1892b). Das Keimplasma. Eine Theorie der Vererbung. Jena: Fischer.

Wilkins, M[aurice] H[ugh] F[rederick]; Stokes, A[lexander] R[awson]; Wilson, H[erbert] R[ees] (1953). "Molecular Structure of Deoxypentose Nucleic Acids". Nature 171/4356, 738-740.

Wilson, Edmund B[eecher] (1896). The Cell in Development and Inheritance by Edmund B. Wilson. New York: The Macmillan Company.

Recibido : 16/05/2017

Aceptado : 12/07/2017

\section{(c) $(1) \Theta$}

ENDOXA está bajo una licencia de Creative Commons Reconocimiento-NoComercial-SinObraDerivada 4.0 Internacional 
